\section{International Scientific Journal Theoretical \& Applied Science}

\author{
p-ISSN: 2308-4944 (print) e-ISSN: 2409-0085 (online) \\ Year: 2017 Issue: $11 \quad$ Volume: 55 \\ Published: $24.11 .2017 \quad$ http://T-Science.org
}

Kymyzai Ahmatovna Dehkanova

candidate of juridical science assistant professor of department of theory of law and government of Osh state university of Kyrgyz Republic

SECTION 32. Jurisprudence.

\title{
SUBSOIL USE AS AN OBJECT OF STATE LEGAL REGULATION
}

Abstract: The article deals with the notion of subsoil and subsoil use, mechanisms for realizing the functions of state authorities in the subsoil use sphere with the aim of improving the legal forms and methods of managing state property and increasing the efficiency of its use.

Key words: subsoil use, state-legal regulation of subsoil, public authorities.

Language: Russian

Citation: Dehkanova KA (2017) SUBSOIL USE AS AN OBJECT OF STATE LEGAL REGULATION. ISJ Theoretical \& Applied Science, 11 (55): 167-170.

Soi: http://s-o-i.org/1.1/TAS-11-55-19 Doi: crossef https://dx.doi.org/10.15863/TAS.2017.11.55.19

\section{НЕДРОПОЛЬЗОВАНИЕ КАК ОБЬЕКТ ГОСУДАРСТВЕННО-ПРАВОВОГО РЕГУЛИРОВАНИЯ}

Аннотация: В статье рассмотрень понятие недр и недропользования, механизмь реализации функиий органов государственной власти в сфере недропользования с иелью совершенствования правовых форм и методов управления государственной собственностью и повышения эффективности ее использования.

Ключевые слова: недропользование, государственно-правовое регулирование недр, органьи государственной власти.

\section{Introduction}

Совершенствование правовых форм и методов управления государственной собственностью, а также повышение эффективности ее использования в нынешних условиях социальноэкономического развития Кыргызстана является важной задачей. Согласно ст.12 Конституции Кыргызской Республики земля, ее недра являются государственной собственностью и составляет потенциал республики [1]. Без полезных ископаемых трудно представить динамичный рост промышленного производства и современную экономику. Особенности Кыргызстана проявляются еще в том, что он обладает значительными запасами полезных ископаемых.

Отечественное законодательство о недропользовании закрепил государственную собственность на недра, разрешительную систему пользования недрами, т.е. лицензирование, механизмы государственного контроля и надзора. Государству для достижения нормального функционирования недропользования нужно создать благоприятную правовую среду и обеспечить свои интересы. При этом необходимо учесть специфику недропользования, так как государство имеет властные полномочия. Также государственное регулирование нужно провести через определенные механизмы реализации функций органов власти. В связи с этим необходимо глубокое осмысление системы органов исполнительной власти, занимающихя процедурами административно-правовым регулированием недропользования. в современной научной литературе.

\section{Materials and Methods}

Механизмы государственно-правового регулирования недропользования в Кыргызской Республике и его составляющие элементы не получили еще необходимого освещения. В связи с чем, есть необходимость фундаментальной теоретической разработки. Из чего и вытекает актуальность исследования данного вопроса $[5$, с. 192].

Люди стали пользоваться недрами как только зашли первый раз в пещеру. Добыча полезных ископаемых является самым распространенным видом пользования недрами. Этому предшествует геологическое изучение, 
которое необходимо для определения запасов, качества руд, выбора способов разработки месторождений. А также еще одним видом пользования недрами является сбор геологических коллекционных материалов, использование недр земли для строительства и эксплуатации подземных сооружений, в т. ч. образование особо охраняемых геологических объектов.

Большинством ученых, изучающихся проблемы использования недр применяется термин «недропользование». Но, само понятие этого термина объясняется по разному. Когда отдельные ученые определяют недропользование как деятельность недропользователей в рамках полученного разрешения на их разработки или заключенного договора о разделе продукции. Другая группа ученых определяют недропользование как предусмотренную и защищаемую законом деятельность пользователя недр, на территории определенного государства, которая направлена на использование полезных ресурсов (полезные ископаемые). Из вышесказанного следует то, что недропользование - это деятельность пользователей недр.

Большинство мнений, высказанных в учебных и научных публикациях по правовым основам недропользования сводятся к тому, что недропользование - это целенаправленная деятельность человека в сфере изучения и использования недр, реализующего свои физические и умственные способности для получения определенных материальных благ, с чем и мы согласны. Поскольку эта деятельность охватывает широкий спектр мероприятий, начиная от геологического изучения недр и кончая освоением подземного пространства [7, с. 88]. Многообразие возможных видов и разновидностей пользования недрами довольно значительно, в связи с чем, возникает необходимость их научной систематизации и классификации, на законодательном уровне.

Формулировка понятия «недропользование» необходимо для определения недропользования как объекта правового регулирования. Для этого нужно рассмотреть вопрос об элементах или стадиях процесса недропользования. Необходимо подчеркнуть, что недропользование это деятельность недропользователей по геологическому изучению, добыче полезных ископаемых и освоению подземных пространств для реализация всех видов пользования недрами [3]. Но это, как известно, только «техническое недропользование», т.е. это «горный промысел».

До начала «технического недропользования» необходимо выполнить определенные мероприятия. Например:

- формирование и опубликование перечней участков недр, аукционы или конкурсы по которым планируется провести;
- установление перечней участков недр, право пользования которыми может быть предоставлено на условиях соглашений о разделе продукции, определение и разработка их условий, согласование и заключение таких соглашений;

- государственная экспертиза геологической информации;

- принятие решения об условиях проведения конкурсов;

- проведение конкурсов;

- лицензирование;

- государственный учет;

- контроль и надзор за деятельностью недропользователей, подведение итогов деятельности [2].

Кроме этого существует другие вопросы, которые также входят в понятие процесса недропользования и без них никакое недропользование не состоится:

- организация органов государственной власти в области недропользования,

- определение и разграничение их полномочий и др.

Bсе это также относится к государственноправовому регулированию недропользования.

Из сказанного следует, что процесс недропользования, как достаточно значимое понятие, включает в себя не только процесс изучения и освоения подземных пространств, но и управленческий процесс, является объектом нашего изучения.

Изучив недропользование как объект государственно-правового регулирования можно сделать вывод о том, что он заключается в деятельности недропользователей. Данная деятельность направлена на рациональное освоение запасов недр с целью воспроизводства полезных ископаемых [4, с. 41].

Допуск частных компаний к недрам оформляется во всех случаях лицензией, выдаваемой государством. Лицензия это административный акт, оформляющий разрешение или допуск субъекта предпринимательской деятельности к недропользованию. По лицензии определяется характер взаимодействия государства и недропользователя., также верховенство государства над недропользователем.

Государство как полноправный хозяин единолично решает, допускать на каких условиях или не допускать разработке участков недр и освоения подземных пространств [6, с. 124]. В этом случае недропользователь - просящий, какими бы правилами о безотзывности лицензий при отсутствии нарушений со стороны недропользователя или невозможности одностороннего изменения условий лицензии закон не обставлял отношения между лицензиатом и лицензиаром. 
При лицензионной системе экономическая ценность прав недропользования состоит в тех правомочиях, которые предоставляются самому недропользователю в отношении участка недр. Например, недропользователь вправе добывать полезные ископаемые, осуществлять их продажу третьим лицам, получая тем самым определенный доход [10, с. 45].

Следует подчеркнуть, что недропользование, является объектом публично-правового регулирования. Предоставляя лицензию недропользователю на проведение геологического изучения и освоения подземных пространств, и заключив соглашение о разделе продукции, государство действует как суверен, носитель публичной власти, а не как собственник имущества.

Для государства одним из эффективных инструментов, позволяющих решать управленческие задачи, не подавляя при этом сферы частной свободы, выступает публично-правовой договор [8]. Использование публично-правовых договоров является особенно актуальным для недропользования, предметная чистота и отраслевая самостоятельность которого основывается на институтах, сочетающих в себе одновременно публичные и частные элементы. Поскольку сфера недропользования находится в области публичного интереса, то государство, являясь единственным собственником ресурсов недр, выступает одновременно в двух качествах: как участник хозяйственного оборота и как выразитель социальных интересов [9, с. 162]. Применение частноправовых инструментов в сфере недропользования невозможно из-за того, что диспозитивные методы регулирования не в состоянии должным образом защитить интересы общества в благоприятной для человека окружающей природной среде при рациональном недропользовании, обеспечить экологическую безопасность, которая гарантируется п.1 ст.48 Конституции КР. Также применение односторонне-властных административных средств также бывает неэффективно. И поэтому сложившихся условиях возникает необходимость сочетания договорных начал с административновластными средствами, т.е. публично-правовой договор.

В процессе недропользования понятие «недра» - это ключевое для правовых отношений. В Конституции Кыргызской Республики не содержится определения понятия «недра». Данный термин употребляется здесь лишь однажды в пункте «5» ст. 12, где сказано, что земля, ее недра и другие природные ресурсы являются исключительной собственностью Кыргызской Республики, используются в целях сохранения единой экологической системы как основы жизни и деятельности народа Кыргызстана и находятся под особой охраной государства.
Первостепенную задачу, подлежащую решению, при моделировании правового регулирования недропользования составляет определение понятия недра и недропользование. В законодательстве заложена модель обособления земельного участка и находящегося под ним пространства, т. е. недра отделены от земли и в силу специального указания закона не могут быть присвоены частным лицом. Хотя в юридико-техническом плане установление различного правового режима земли и недр создает определенные сложности, политически и экономически такое обособление оправданно. Предложенная модель позволяет сохранить недра как стратегический экономический ресурс в монопольной государственной собственности, одновременно допустив введение частной собственности на землю и, как следствие, ее активное участие в гражданском обороте $[15$, с. 34]. Кроме того, причиной обособления служит то, что земля и недра служат различным хозяйственным целям.

Владение, пользование и распоряжение природными богатствами недр земли осуществляются в большинстве стран с согласия государства. Данная практика установилась исходя из общепризнанной международной нормы о том, что владение, пользование и распоряжение природными богатствами своей страны, и в частности недрами и их ресурсами, рассматривается как неотъемлемый элемент суверенитета каждого государства [14, с. 137]. Поскольку земля и недра обособлены как объекты права, необходимо установить, где проходит граница между ними. Согласно действующему законодательству недра являются частью земной коры, расположенной ниже почвенного слоя, а при его отсутствии - ниже земной поверхности и дна водоемов и водотоков. Данное определение вполне соотносится с тем, что земельный участок представляет собой площадь земли в замкнутых границах (п.4 ст. 1 Земельного кодекса КР). Данные вопросы регламентируются нормами Земельного кодекса Кыргызской Республики, в частности, предоставление земельных участков для пользования недрами (ст.28), порядок предоставления земель под недропользование (28-1), условия застройки площадей залегания полезных ископаемых (ст.28-2), пользование земельным участком при геологическом изучении недр (ст.28-3).

Другой вопрос состоит в том, что именно в пределах верхней и нижней границы следует относить к недрам. Действующее законодательство справедливо считает недрами не только

a) подземное пространство с содержащимися в нем полезными ископаемыми,

б) все прочие горные породы, которые не относятся к полезным ископаемым [13, с. 94]. 
Поэтому государство, заинтересованное в охране недр, и установило, что объектом права его исключительной собственности являются не только полезные ископаемые, но и все содержимое недр.

Тогда недропользование как объект государственно-правового регулирования - это урегулированная нормами права деятельность недропользователей, призванная обеспечить изучение и рациональное освоение недр земли в различных целях для получения определенных материальны и духовных благ [12, с. 51].

А государственно-правовое регулирование недропользования может быть определено как регламентированная нормами права деятельность наделенных властными полномочиями государственных органов и должностных лиц по организации рационального освоения и охраны ресурсов недр, воспроизводству полезных ископаемых, а также обеспечению благоприятных условий жизнедеятельности и экологической безопасности общества $[11$, с. 18$]$.

\section{Conclusion}

В данном определении исключается деятельность муниципальных органов, поскольку недра находятся в ведении Кыргызской Республики и являются государственной собственностью; полномочиями по управлению (в т. ч. по представлению лицензий) должны обладать только государственные органы власти. Включение положений о предоставление разрешений органами местного самоуправления на разработку месторождений общераспространенных полезных ископаемых и участков недр местного значения противоречит Конституции Кыргызской Республики, и может привести к разногласиям.

\section{References:}

1. (2010) Konstitutsiya Kyrgyzskoy Respubliki: prinyata referendumom (vsenarodnym golosovaniyem) 27 iyunya 2010 goda; vvedena v deystviye Zakonom Kyrgyzskoy Respubliki ot 27 iyunya 2010 goda). - Rezhim dostupa: Available: http://www.toktom.kg (Accessed: 10.11.2017).

2. (2006) Zemel'nyy, Lesnoy, Vodnyy, Vozdushnyy kodeksy Kyrgyzskoy Respubliki.B.:Akademiya, 2006, 568 p. Izd. Akademiya.

3. (2013) Zemel'nyy kodeks Kyrgyzskoy Respubliki. Vveden v deystviye Zakonom KR ot 2 iyunya 1999 goda №46.B.: «Kenesh», 2013.-68 p.

4. Teplov O.M. (1995) Pravovyye osnovy predostavleniya prav pol'zovaniya nedrami. Gosudarstvo i pravo, 1995, N 12. p.41.

5. Spiridonov L.I. (1996) Teoriya gosudarstva i prava. M., 1996. p.192.

6. Atamanchuk G.V. (1997) Teoriya gosudarstvennogo upravleniya. Kurs lektsiy. M.: Yuridicheskaya literatura.

7. Bashmakov G.S. (1974) Pravo pol'zovaniya nedrami v SSSR. M.: Izd-vo «Nauka».

8. YU.Bel'skiy K.S. (1997) O funktsiyakh ispolnitel'noy vlasti // Gosudarstvo i pravo. 1997.-№3.
9. N.Brinchuk M.M. (1998) Ekologicheskoye pravo (pravo okruzhayushchey sredy): Uchebnik dlya vysshikh uchebnykh zavedeniy. M.: Yurist".

10. Bystrov G.Ye. (1999) Pravovoye regulirovaniye litsenzirovaniya pol'zovaniya nedrami // Pravovyye problemy neftegazovogo kompleksa. Sbornik nauchnykh trudov (vyp. 1) / Pod red. Kleandrova M.I., Klotsa O.I. Tyumen': Izdatel'stvo "Vektor Buk".

11. Golichenkov A.K., et al. (2000) Problemy ekologicheskogo, zemel'nogo prava i zakonodatel'stva // Gosudarstvo i pravo. 2000. № 5 .

12. Gurney B. (1969) Vvedeniye v nauku upravleniya. Moscow.

13. Zaslavskaya Jl.L. (1969) O ponyatiyakh ob"yekta prava gosudarstvennoy sobstvennosti na nedra zemli i pol'zovaniye imi. Uchenyye zapiski VNIISZ. Vyp. 16. Moscow.

14. Kalinin I.B. (2001) Pravovoye regulirovaniye resursopol'zovaniya. Tomsk: Izd-vo NTL.

15. Kozbanenko V.A. (2003) Pravovyye osnovy gosudarstvennogo upravleniya. Obshchaya chast': Uchebnoye i nauchno-prakticheskoye posobiye. M.: IKF «EKMOS». 